\title{
Валентин Іваненко
}

Дніпровський національний університет ім. Олеся Гончара

\section{Жебрацтво та бродяжництво у повсякденному житті Півдня України 1920-х років}

У статті актуалізовано й проаналізовано недостатньо досліджений ракурс регіональної історії, пов'язаний 3 виявленням і характеристикою сутнісних ознак, соціально-економічних чинників та особливостей поширення жебрацтва і бродяжництва як органічних складників у структурі девіантних явищ повсякденного життя Південної України в період непу. На підставі сучасних теоретико-методологічних підходів і методів та репрезентативних джерел (в тому числі архівних) доведено, що найпотужнішими каталізаторами їх тогочасного сплеску стали руйнівні наслідки Першої світової та Громадянської воєн, тотальна розруха, голод 1921-1923 pp., міграції, безробіття тощо. Опрацьовано і оприлюднено відповідні статистичні дані. Встановлено і описано спорідненість (спільне коріння) жебракування та бродяжництва, породжених довготривалою і всеохопною кризою суспільства, тотальним і стрімко наростаючим зубожінням та маргіналізацією населення, появою великих мас знедолених людей на Півдні республіки, позбавлених елементарних засобів біоіснування, відсутністю скоординованої і ефективної системи їх соціальної підтримки 3 боку радянської влади та громадськості.

Автором наголошено, що при всіх недоліках, прорахунках та суперечностях тодішніх більшовицьких кроків щодо очищення «соціального дна» в регіоні й реінкарнації його носіїв в русло нормального, повноцінного життя цей повчальний історичний досвід не втратив певною мірою своєї злободенності і в наші дні, а отже міг би стати в нагоді при розробці та реалізації відповідних соціальних програм в Україні, де під впливом глибоких трансформаційних процесів, інтенсивного майнового розшарування суспільства, прогресуючої бідності більшості громадян стабільно фіксується достатньо високий рівень подібних аномалій.

Ключові слова: Південна Україна, голод, міграції, радянська влада, аномалії, жебрачтво, бродяжничтво

\section{Valentyn Ivanenko \\ Oles Honchar Dnipro National University}

\section{Begging and vagrancy in everyday life in the South of Ukraine in the 1920s}

The insufficiently studied perspective of regional history related to the identification and characterization of essential features, socio-economic factors and features of the spread of begging and vagrancy as organic components in the structure of deviant phenomena of everyday life in southern Ukraine during the NEP actualizes and analyzes in the article. On the basis of modern theoretical and methodological approaches and methods and representative sources (including archival) it is proved that the most powerful catalysts of their then surge were the devastating consequences of the First World and Civil Wars, total devastation, famine of 1921-1923, migration, without migration. Relevant statistical data have been processed and published. The kinship (common roots) of begging and vagrancy caused by the long-lasting and all-encompassing crisis of society, total and rapidly growing impoverishment and marginalization of the population, the emergence of large masses of disadvantaged people in the South of the republic, deprived of basic social support by the Soviet authorities and the public.

The author emphasizes that despite all the shortcomings, miscalculations and contradictions of the then Bolshevik steps to clean the "social bottom" in the region and reincarnate its bearers in the course of normal, full life, this instructive historical experience has not lost some of its relevance today, and therefore could be useful in the development and implementation of appropriate social programs in Ukraine, where under the influence of deep transformation processes, intensive property stratification of society, progressive poverty of the majority of citizens, a fairly high level of such anomalies is consistently recorded.

Keywords: Southern Ukraine, famine, migrations, Soviet power, anomalies, begging, vagrancy 


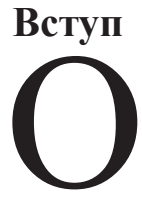

днією із сумних прикмет нашого українського сьогодення $\epsilon$, як відомо, дедалі прогресуючі процеси майнового розшарування, масового зубожіння і маргіналізації населення, коли на одному полюсі суспільства спостерігається стрімка й майже неконтрольована концентрація ресурсів у руках відносно мізерної частини супер багатих людей (олігархів), а на іншому - безпросвітна бідність мільйонів громадян, особливо iз середовища так званих незахищених категорій, пенсіонерів. Саме це здебільшого й стимулює стале «підживлення» соціуму різними аномальними контингентами, починаючи, напевно, якраз із бродяг та жебраків, загальна чисельність яких в Україні незмінно сягає кількох десятків тисяч (лише офіційно). Причому абсолютна ï більшість - люди працездатного віку (Соціальні індикатори ..., 2000, с. 170).

Яким чином боротися 3 наростаючим валом подібних суспільних девіацій (а це ще й дитяча безпритульність, бомжування, пияцтво, наркоманія, проституція тощо), які механізми, важелі та засоби мають бути задіяні у площину практичних кроків властей та громадськості - ці та інші далеко не риторичні питання нині неабияк хвилюють багатьох, спонукаючи до роздумів і пошуку відповідних рішень.

Вданомуконтекстідоцільниміактуальним уявляється звернення до історичного досвіду та уроків минулого, зокрема непівської доби, що могли б слугувати певним теоретикометодологічним орієнтиром і практичним прикладом при виробленні державної політики протидії таким явищам у сучасних умовах. Щоб, як кажуть, двічі не наступати на одні й ті ж «історичні граблі».

Саме цей чинник мотивував автора до написання статті, метою якої є аналітична реконструкція причинно-наслідкового зрізу проблеми жебрацтва і бродяжництва як органічних складників у структурі девіантних явищ повсякденного життя населення Південної України в період непу.

Методи дослідження: історикогенетичний, проблемно-хронологічний, компаративний, міждисциплінарний, логічний.

Огляд досліджень і публікацій.

В умовах інтенсивного переосмислення радянської спадщини українська історична наука дедалі глибше занурюється у незвідані iï пласти чи утаємничені криївки, постійно розширюючи й збагачуючи проблемнотематичний ареал досліджень, зокрема, за рахунок міждисциплінарної інтеграції, тобто сфер, які ще донедавна були у фокусі наукових зацікавлень переважно соціологів, психологів, юристів та ін. Власне, на такому дослідницькому тлі й розгорнулося системне вивчення вітчизняної соціальної історії, мікроісторії, історії повсякдення, що стали невід'ємною органічною компонентою історіографічного процесу. Проблема соціальних аномалій чи девіацій на різних етапах соціалістичного минулого в цьому ж ряду.

$\mathrm{He}$ обійденою в даному контексті виявилася, звісно, й непівська доба, тим паче що спонукальних мотивацій до їх виникнення та поширення в ті часи було більш ніж достатньо. Маємо на увазі щонайперше спустошливі наслідки Першої світової і Громадянської воєн, тотальну розруху, голод 1921-1923pp., міграції, безробіття тощо. Проте цей ракурс нашої тогочасної соціальної історії досліджений ще явно недостатньо, багато в чому поверхово, сегментарно, 3 перекосами. Найбільш повно, на наш погляд, в науковій літературі відпрацьована поряд з голодним лихоліттям В. Іваненко (2016, с. 45-54) проблема дитячої безпритульності в непівській Україні, що засвідчують інформаційно насичені, побудовані переважно на маловідомих, а то й зовсім невідомих архівних джерелах праці Г. Салька (1931), С. Чеха (1953), А. Гусака (1976), І. Діптан (1992, с. 52-60), А. Зінченко 
(1998, с. 78-85), О. Паращевіної (2005) та ін. Хоча перші з них, як і більшість радянських історіописань соціального спрямування, були виконані так чи інакше в дусі відповідних політико-ідеологічних впливів епохи, оскільки ігнорування ключового в ті часи методологічного принципу партійності в науці могло обернутися для авторів неприємними наслідками аж до покарання по партійній лінії чи звільнення з роботи.

Натомість інші соціальні негаразди 1920-х років, в тому числі бродяжництво та жебракування, й досі не знайшли адекватного відображення в історіографії. Однією 3 перших спроб комплексного осмислення «аномальної» тематики цієї пори зробили ми з I. Іщенком (2006), проте, як на мене, вона потребує подальших дослідницьких кроків із залученням нових масивів документальних джерел та сучасних концептуальних підходів.

\section{Результати дослідження}

Як відомо, витоки жебрацтва та бродяжництва на вітчизняних теренах своїм корінням сягають вглиб віків, будучи невід'ємними супутниками повсякденного життя багатьох поколінь українців. До таких занять зазвичай вдавалися немічні, убогі, хворі, 3 явними фізичними вадами люди (каліки), які не могли віднайти засоби існування традиційними шляхами. Допомагати ж нужденним, знедоленим у всі часи вважалося справою благочинною, шляхетною. Разом 3 тим здоровим, працездатним часто офіційно заборонялося блукати по людних місцях $\mathrm{i}$ просити милостиню, «понеже в таковых многие за леностями и молодые, которые в работы и наймы не употрябляются, милости просят, о которых ничего доброго, кроме воровства, показать не можно».

Утім, в історичній ретроспективі становлення та розвитку української нації було чимало лиховісних періодів, коли жебрацтво і бродяжництво виходили далеко за межі звичних уявлень й охоплювало досить великі маси злиденних людей, котрі за фатальним збігом різноманітних обставин потрапляли у вир жорстоких економічних негараздів, балансуючи, по суті, між життям і смертю. У них не залишалося нічого іншого, як вдаватися до подібних дій. Причому особливого розмаху ці соціальні метаморфози набирали на крутих, переломних етапах нашої історії, у часи глибоких трансформаційних змін та стихійних лих, що супроводжувались неминучим загостренням системних протиріч, кризових явищ, зубожінням значних верств населення i, як наслідок наростанням соціальної напруженості та аномальних потоків у суспільстві.

Не стали винятком у цьому відношенні й суперечливі 1920-ті роки минулого сторіччя, позначені, 3 одного боку, позитивною динамікою відродження української економіки та іï реформування на засадах непу, а $з$ іншого - негативними процесами тотальної розрухи, зростання безробіття, поглиблення руйнівної дії декласування промислових робітників, соціального розшарування міста і села, бюрократизації суспільного життя, згортання ринкової парадигми господарювання тощо. У початковий період мирного будівництва ще більше загострив ситуацію в Україні, особливо на теренах іiі південної частини, голод 1921-1923 pр., котрий спалахнув тут, на думку відомого історика С. Кульчицького, не тільки через природні катаклізми (страшенна посуха, а звідси й цілком прогнозований неврожай), деградацію продуктивних сил республіки внаслідок тривалих воєнних дій, а й через згубну для народного господарства економічну політику державної партії та підлегле становище формально незалежної УСРР щодо московського центру (Кульчицький, С., 1999, с. 24).

Ті драматичні роки стали своєрідним моральним полігоном випробувань людської гідності та честі, здатності боротися за життя особисте й своєї родини, близьких, 
друзів. I далеко не всі змогли достойно витримати ці випробування, вийти 3 них переможцями. Багато людей опинились у лещатах небувалої економічної скрути, морального відчаю і від безвиході почали жебракувати. Звертає на себе увагу така деталь: якщо стихія об'єктивно вплинула на загальний психологічний стан населення та його деморалізацію, то протидія ії наслідкам мала переважно суб'єктивний характер. У даному випадку йдеться про незграбні дії і відверте політиканство властей під час голоду, особливо в початковий період. Так, саме через політико-ідеологічні чинники центральний уряд довго блокував доступ «буржуазних» благодійницьких організацій Заходу у південний регіон УСРР. Перший дозвіл на подання допомоги голодуючим цього краю меноніти, приміром, отримали лише в березні 1922 р., а АРА та інші зарубіжні місії змогли розпочати тут практичну діяльність тільки у травні того ж року, коли від голоду вже гинули тисячі й тисячі людей (Осташева, Н., 1998, с. 75).

Дослова, зарубіжнадопомогаголодуючим тривала до літа 1923 р. У серпні 1922 р., коли закордонні благодійники на повні оберти розгорнули свою роботу в Україні, вони харчували 1,8 млн. мешканців неврожайних (читай: південних) губерній проти 400 тис., що забезпечувались ЦК Допгол при ВУЦВК (Кульчицький, С., 2013, с. 63). Всього за період цієї акції голодуючі українці отримали від Міжробдопу (організація створена під егідою Комінтерну) 383 тис. пайків, Міжнародного союзу допомоги дітям - 3 млн., Американської менонітської допомоги - 7,1 млн., місії норвезького полярного дослідника Ф. Нансена 12,2 млн., а від Американської адміністрації допомоги (АРА) на чолі 3 майбутнім 31-м президентом США Г. Гувером - 180,9 млн. пайків (Литвин, В., 2003, с. 27).

Тим часом ще у грудні 1921 р. український уряд оголосив повністю голодуючими Запорізьку губернію, Таганрозький i Маріупольський повіти Донецької, Дніпровський, Херсонський, Миколаївський повіти Миколаївської, Одеський i почасти Тираспольський повіти Одеської, Катеринославський, Криворізький і частину Дніпровського повіту Катеринославської, Кобеляцький та Константиноградський повіти Полтавської губернії.

Кількість голодуючих катастрофічно збільшувалася. Тільки в степовій зоні України вона зросла 3 грудня 1921 р. по травень 1922 р. більше ніж утричі - 3 1,2 до 3,8 млн. осіб (Мовчан, О., 1991, с. 28).

Безперечно, голод був одним із основних джерел зростання жебрацтва та бродяжництва. В Одесі, наприклад, у серпні 1922 р. налічувалося до 30 місць найвищої концентрації жебраків, тоді як рік тому їх було вдвоє менше (Держархів Одеської обл., ф. Р-107, оп. 1, спр. 482, арк. 2-13). Згубний удар по населенню, особливо по селянах, нанесли й інші лиха - недороди, градобої, посухи, що траплялись на Півдні України в роки непу, внаслідок чого багато селян, виснажених попереднім лихоліттям, вдалися до жебракування (Держархів Микол. обл. ф. Р-616, оп. 1, спр. 22, арк. 4).

Водночас однією 3 причин тодішнього поширення в суспільстві цього явища були епідемії інфекційних хвороб. Зрозуміло, що під час голоду знижувався опір організму, а тому їх і спалахувало чимало. За даними Наркомату охорони здоров'я УСРР, тільки за сім місяців 1922 р. у неврожайних губерніях республіки хворіло на холеру 24,4 тис. осіб, на черевний тиф - близько 29,6 тис., на висипний - 136,6 тис., на поворотний $-141,7$ тис. осіб. Помітно зросла смертність населення. Тяжкий стан склався у Катеринославі, Одесі, Миколаєві, Бердянську та навколишніх селах, що, окрім іншого, означало розпад тисяч сімей, збільшення числа сиріт та інших потенційно аномальних груп. У ході опитування жебраків Катеринослава у березні 1925 p. $14 \% 3$ них назвали хворобу як основну 
причину свого заняття, 13\% - старість, 17\% - інвалідність, 18\% - бездомність (ЦДАВО Укр. ф. 582, оп. 1, спр. 159, арк. 122; ф. 5, оп. 2, спр. 809, арк. 9).

Руйнування значної частини селянських господарств внаслідок голоду різко стимулювало міграційний бум селян до міста. Тогочасні офіційні повідомлення рясніли тривожними сигналами про масові зубожіння селян, про тих, хто покинув свої домівки й помандрував у місто. Завдання щодо охорони таких садиб були покладені на районні та сільські комітети взаємодопомоги (Іваненко, В. та Іщенко, В., 2006, с. 110). Проте переважна більшість цих структур просто ігнорувала вказівки зверху, і багато переселенців, повернувшись до своїх осель, знаходили їх повністю розкраденими, про що свідчать, зокрема, доповіді голів райвиконкомів Катеринославщини у серпні 1923 р. Із 130 волосних та сільських комітетів взаємодопомоги губернії тільки Кам'янський та Краснопільський дійсно піклувалися про людей і допомагали їм, а решта існувала лише на папері (Держархів Дніпропетр. обл., ф.Р-305, оп. 2, спр. 1а, арк. 616 ; оп. 1, спр. 18, арк. 38,50).

Серед розмаїття об'єктивних факторів, що викликали сплеск жебрацтва в Україні у роки непу, центральне місце все ж таки належить безробіттю, підтвердженням чого слугують результати дослідження цього явища у Катеринославі. Саме такою причиною пояснили свій спосіб існування кожний третій респондент (ЦДАВО Укр., ф. 5, оп. 2, спр. 809, арк. 9). Особливістю безробіття 1920-х років у республіці було його переважно аграрне походження. Адже лави безробітних збільшувалися не тільки і не стільки за рахунок промислових робітників, скільки тих українських селянбідняків, які прагнули знайти роботу в місті. Найбільшого поширення ця тенденція набула у таких містах, як Київ, Харків, Одеса, Катеринослав, Миколаїв. Крім того, з-поміж безробітних чимало було й колишніх червоноармійців, що так і не знайшли свого місця в нормальному житті. Тож не дивно, що частина 3 них змушена була зайнятися жебрацтвом. Тільки серед жебраків Катеринослава їх доля досягала 15\% (ЦДАВО Укр., ф. 5, оп. 2, спр. 809, арк. 9).

При цьому офіційна статистика про кількісний склад безробітних і реальні дані дуже різнилися. За переписом населення, проведеним у грудні 1926 р., 194,4 тис. осіб вказали на те, що не мають роботи, а біржі праці фіксували на той час 410,3 тис. таких людей. Щоправда, до списків безробітних подекуди потрапляли особи, які просто ухилялися від праці, тобто вважалися за радянською термінологією дармоїдами. Ясна річ, приваблювала їх щонайперше можливість отримувати певні пільги: безкоштовні обіди, право на пільгові комунальні послуги тощо (Іваненко, В. та Іщенко, І., 2006, с. 111).

Безробітні України тих часів належали в основному до категорії осіб з низькою кваліфікацією або й зовсім без неї. Більшість iз них не мали шансів одержати постійну роботу, а тому частина їх під тиском обставин просто змушена була жебракувати (Держархів Дніпропетр. обл., ф. Р-122, оп. 1, спр. 45, арк. 53). Додамо також, що нічліжні будинки для безробітних, у яких найчастіше опинялися приїжджі селяни та інші «шукачі» кращої долі, були розсадниками пияцтва, розпусти, аморальності. Звісно, перебування в них негативно впливало на людину, яка вперше туди потрапляла, внаслідок чого багато новачків, спілкуючись 3 постійними мешканцями нічліжок, буквально у лічені дні починали переймати їхнє нехитре «рукопротяжне ремесло» (Звезда, Екатеринослав, 1923, 26 сент.).

Гадаємо, не буде перебільшенням сказати, що у будь-якому суспільстві були, $є$ i, мабуть, ще довго будуть бідняки, жебраки, бродяги, безхатченки (бомжі), п’яниці, наркомани, проститутки і злочинці різних 
мастей та відтінків. Об'єктивно такі люди об'єднуються за спільною ознакою - жити за рахунок інших, чого вони завжди і в усьому свято дотримуються. Ці референтні групи, існуючі у суспільстві, по суті, $€$ його вигнанцями. Вони створили свою субкультуру зі своїми традиціями, устроєм життя тощо. Багато 3 них вже не могли адекватно протистояти труднощам життя, викликам часу, систематично працювати, а тому здебільшого жебракували, просили переважно лише на їжу та горілку, запасів не робили, не гребуючи й дрібними крадіжками (Держархів Дніпропетр. обл., ф. 1, оп. 1, спр. 633, арк. 87).

Для типового представника «рукопротяжної фабрики», і 1920-ті роки це красномовно підтверджують, були властиві такі риси, як відсутність самолюбства, сорому, стримуючих мотивів для крадіжки, лінощі, брехня, неробство, розпуста. Колишнє життя для такої людини ставало дедалі обтяжливішим, боротися за нього вже не вистачало ані сил, ані енергії. Зрештою це являє собою не що інше, як хворобу, a iii діагноз - пауперизм (жебракування). Причому типологія цієї аномалії за часів непу представлена досить широким спектром - від громадян, які вперше відчули себе «на дні» суспільства, загнані у глухий кут екстремальними обставинами, до тих, хто свідомо зробив свій вибір на користь подібного способу життя, поповнивши лави професійного жебрацтва. Як би там не було, взагалі жебрацтво, мабуть, можна бодай образно порівняти із своєрідною кар'єрою, яку неможливо покинути.

Жебракування нерозривно пов'язане i 3 такою соціальною хворобою, як бродяжництво. У роки непу в Україні юридичного обгрунтування терміну «бродяжництво» не існувало. Найчастіше тоді використовувалося словосполучення «бродячий елемент». До цього контингенту включали всіх громадян, які не мали відповідного посвідчення, а точніше, дозволу властей на проживання в конкретній місцевості. Швидке поширення явища спонукало державні інституції вжити щодо його носіїв запобіжні, каральні заходи, переважно у вигляді адміністративної відповідальності (Держархів Дніпропетр. обл., ф. Р-1379, оп. 1, спр. 1, арк. 212-215).

Примітний штрих: в 1920-ті роки практично кожний селянин, що прибув до міста у пошуках роботи чи просто елементарних засобів існування, міг бути зарахований до «бродячого елемента», оскільки селянам, якщо вони не залучалися до громадських робіт, офіційно заборонялося перебувати більше двох тижнів у гуртожитку чи нічліжному будинку. Тому багато 3 них мандрували далі, до інших міст, хоч, як правило, й не на далекі відстані. Разом 3 вихідцями із села бродяжничали також міські жебраки, головним чином з числа бездомних. У цілому до 60\% жебраків одночасно були бродягами (Іваненко, В. та Іщенко, I., 2006, c. 115,116$)$, що свідчить про збіг факторів поширення цих двох соціальних явищ у період непу.

Потужним фактором нарощування таких людей в південноукраїнських містах біли міграційні потоки переважно із сусідньої Росії. Особливих масштабів вони досягли під час голоду 1921-1923 рр., коли із Поволжя та інших охоплених цим лихом російських регіонів в Україну прибули 429 тис. біженців, 3 них до 80 тис. дітей. У 1922 р. три чверті дитбудинківців були біженцями від голоду (Голод 1921-1923 років в Україні..., 1993, с. 13).

Проблему бродяжництва помітно загострила триваюча в республіці дитяча безпритульність. Так, у 1926 р. на залізниці та інших шляхах сполучень Південної України було зафіксовано 2084 бродячих дітей (ЦДАВО Укр., ф. 3, оп. 1, спр. 3666, арк. 309).

Хвилі мігрантів з Росії спостерігалися протягом усієї непівської доби. При цьому, як показує аналіз відповідної статистики, 
бродяжничали здебільшого чоловіки селянського походження. На період веснянопольових робіт вони поверталися у рідні місця, а закінчивши сівбу, знову вирушали до міст. Така ж послідовність їх міграції зберігалась у серпні, під час збору врожаю (Держархів Дніпропетр. обл., ф. Р-305, оп. 2, спр. 19, арк. 557). Друга категорія бродяг була представлена гастролерами-злочинцями, що робили ставку на крадіжки, пограбування тощо. Нерідко вони мандрували цілими групами з Одеси, Кавказу, Росії та інших регіонів. Особливо їх вабили портові міста, де об'єктивно існувало більше можливостей поживитися.

Середній вік жінок, які приїжджали до них зазвичай без документів, коливався від 16 до 31 року. Максимальною «жіноча хвиля» була у травні, коли починалася навігація $\mathrm{i}$ до портових міст прибували ділові люди з метою укладення різного роду бізнесових угод. 3-поміж них виділявся Миколаїв, який ще 3 дореволюційних часів вважався одним із найбільших центрів півдня Росії щодо поширення проституції, а період непу лише підтвердив таку його «репутацію»: під час навігації від 25 до 33\% представниць «найдавнішої професії» були мандрівницями з Росії (Іваненко, В., Іщенко, I., 2006, с. 116).

У контексті бродяжництва, вочевидь, варто розглянути етнічні міграції певних груп населення. Йдеться передусім про циган, які бродяжничали по території республіки. Вони, звісно, кочували туди і там, де було більше людей, що зумовлювалось їхніми заняттями - торгівлею кіньми, ковальством, музиченням, ворожінням, жебракуванням тощо. Це змушувало циган розпорошуватися на невеликі групи. Щоправда, в Україні «своїх» кочових циган у досліджуваний період було мало. Основу їх складали прибулі 3 інших регіонів Союзу, іноді приходили й із зарубіжжя, як, приміром, у 1928 р., коли, крім радянських, тут з'явилися цигани 3 Угорщини та Сербії, що перейшли кордон ще за часів революції. Влітку по Україні кочували також кримські та бессарабські табори. Мандрували цигани здебільшого не кіньми, а потягами, і з територією України були зв'язані не дуже міцно. Осілі ж цигани мешкали переважно у великих містах i виїжджали на село тільки на ярмарки чи поворожити. За даними перепису населення 1926 р., в Україні проживало

579 циган. Майже кожен п'ятий 3 них був мешканцем південних округів (Баранников, O., 1931, c. 6, 21).

Показово, що найбільше приваблювали циган великі південні міста - Катеринослав (Дніпропетровськ) та Одеса, де вони отримували достатній прибуток. Однак існує принципова різниця між етнічним переміщенням циган та бродяжництвом аномальних контингентів, оскільки, на відміну від жебраків чи повій, цигани не втратили людської гідності. Хоча певна їх частина, втім як і інших національних груп, займалась тим же. Відомо, що понятійна категорія «жебрацтво» у них завжди втілювалась у специфічній формі, яку чи не найвлучніше характеризує термін «циганити».

\section{Висновки}

Отже, жебрацтво та бродяжництво вкупі 3 іншими соціальними девіаціями набули значного розмаху в Південній Україні за непівських часів, ставши звичайними супутниками ii повсякденного життя. Як встановлено вище, ці аномалії мали спільне походження. Вони спричинялися й живилися здебільшого із середовища безробітних i так званих декласованих, маргінальних елементів, кількісні характеристики яких мали сталу тенденцію до зростання внаслідок перманентного скорочення робочих місць та закриття збиткових, нерентабельних підприємств, особливо в перші роки непу. Глибока системна криза, тотальна розруха, занепад продуктивних сил, фізична i моральна виснаженість «людського чинника» через тривалі воєнні дії 
на території республіки, слабкість державної влади та ii неспроможність впоратися 3 валом політичних і економічних труднощів повоєнного життя радянської країни - все це було тим благодатним підгрунтям, на якому виникали й розросталися подібні соціальні збочення.

I все ж найбільшим лихом для південного регіону УСРР став голод 1921-1923 рр., який викликав масове зубожіння всіх верств населення й неминучий у таких випадках спалах різних соціальних негараздів та аномалій. Ситуацію істотно ускладнювали інтенсивні міграційні потоки до промислових центрів Півдня України, особливо із сусідньої Росії, що не супроводжувалися розгортанням необхідної соціальної інфраструктури. Це не тільки створювало додаткові труднощі та клопоти для місцевих властей, а і вносило значну дезорганізацію у хід вирішення невідкладних соціальних проблем регіону. В таких умовах девіантна поведінка стала для багатьох мігрантів (як українських, переважно селян, так і російських громадян) мало не нормою повсякденного буття, своєрідним «інструментом», за допомогою якого вони швидко адаптувалися до так званої «барачної» субкультури і «цінностей дна» міської цивілізації.

У свою чергу, i сам неп з позицій владного дискурсу являв собою епоху своєрідного аномічногостанусуспільства,зякогоправляча партія усіляко намагалася його вивести, декларуючи i утверджуючи принципово нові ціннісні імперативи людського буття. Ці прагнення віддзеркалились у появі цілої низки нормативних актів, у яких окремі соціальні явища чітко кваліфікувались як девіантні. Власне, на такому правовому полі й розгорталася спільна боротьба влади і громадськості за поступове викорінення соціальних хвороб - «пережитків минулого» - із практики повсякденності будівничих молодої радянської держави. Незважаючи на явно політизоване забарвлення цієї діяльності та романтичну наївність пї організаторів, нагромаджений в ті роки досвід (як позитивний, так і негативний) у ключових, найважливіших складниках своєї актуальності не втратив і дотепер, потребуючи серйозного, неупередженого осмислення і творчого використання у ході суспільної протидії сплеску аналогічних аномалій сьогодення.

\section{БІБЛІОГРАФІЧНІ ПОСИЛАННЯ}

Баранников О.П., 1931. Українські цигани. Київ, 60 с.

Голод 1921-1923 років в Україні: зб. докум. і матер., 1993. Київ, 237 с.

Гусак, А.А., 1976. Комсомол - помощник Коммунистической партии в борьбе с детской беспризорностью на Украине (1921-1925 гг.). Дис....канд. ист. наук, Днепропетровск, 199 с.

Державний архів Дніпропетровської області.

Державний архів Миколаївської області.

Державний архів Одеської області.

Діптан, I.І., 1992. Проблема дитячої безпритульності на Україні (1919-1932рр.). Проблеми історії України: факти, судження, пошуки. № 2. С. 52-60. Київ.

Звезда (Екатеринослав), 1923, 26 сент.

Зінченко, А.Г., 1998. Безпритульність як соціальне явище (До історії розв’язання проблеми). Соціальна політика і соціальна робота. № 1/2. С. $78-85$.

Іваненко, В.В., 2016. Голодне лихоліття 1921-1923 років на Катеринославщині: погляд через десятиліття. Придніпров’я: історико-краєзнавчі дослідження: зб. наук. пр. Дніпропетровськ: Дніпровський національний університет імені Олеся Гончара, вип. 14, с. 45-54.

Іваненко, В.В., Іщенко, І.В., 2006. Україна непівська: аналіз соціальних аномалій південного регіону. Монографія. Дніпропетровськ, 280 с.

Кульчицький, С.В., 1999. Україна між двома війнами (1921-1939рр.). Київ, 336 с.

Кульчицький, С.В., Мовчан, О.М., 1993. Невідомі сторінки голоду 1921-1923 рр. в Україні. Київ, 48 с.

Кульчицький, Станіслав, 2013. Червоний виклик. Історія комунізму в Україні від його народження до загибелі. У 3 кн. Київ, кн. 2, 628 с.

Литвин, В.М., 2003. Україна: міжвоєнна доба (1921-1938рр.). Київ, 512 с.

Мовчан, О.М., 1991. Голод 1921-1923 рр. на Україні. Проблеми історії України: факти, судження, пошуки. № 1. С. 24-35. Київ.

www.grani.org.ua 
Осташева, Н.В., 1998. На переломе эпох... (Менонитское сообщество Украины в 1914-1931 гг.). Москва, 253 с. Паращевіна, О.С., 2005. Роль системи народної освіти у подоланні дитячої безпритульності в 20-х - першій половині 30-х рр. XX ст. в Україні. Дис....канд. іст. наук. Дніпропетровськ, 250 с.

Салько, Г.С., 1931. Безпритульність та боротьба з нею. Харків; Київ, 48 с. Київ.

Соціальні індикатори життя населення: Статистичний збірник Державного комітету статистики України, 2000.

Центральний державний архів вищих органів державної влади та управління України (ЦДАВО).

Чех, С.М., 1953. Мероприятия Коммунистической партии и Советского правительства по борьбе с детской безпризорностью в период 1917-1923 гг. Дис....канд. пед. наук. Київ, 269 с.

\section{REFERENCES}

Barannikov, O.P. (1931). Ukrainski tsyhany [Ukrainian gypsies]. Kyiv [in Ukrainian].

Holod 1921-1923 rokiv v Ukraini: zb. dokum. i mater. [The famine of 1921-1923 in Ukraine: coll. document. and mater]. (1993). Kyiv [in Ukrainian].

Gusak, A.A. (1976). Komsomol - pomoshhnik Kommunisticheskoj partii v bor'be s detskoj besprizornost'ju na Ukraine (1921-1925 gg.) [Komsomol - assistant of the Communist Party in the fight against child homelessness in Ukraine (19211925)]. Candidate`s thesis. Dnepropetrovsk [in Russian].

Derzhavnyi arkhiv Dnipropetrovskoi oblasti [The State Archives of Dnipropetrovsk region] [in Ukrainian].

Derzhavnyi arkhiv Mykolaivskoi oblasti [The State Archives of Mykolaiv region] [in Ukrainian].

Derzhavnyi arkhiv Odeskoi oblasti [The State Archives of Odessa region] [in Ukrainian].

Diptan, I.I. (1992). Problema dytiachoi bezprytulnosti na Ukraini (1919-1932 rr.) [The problem of child homelessness in Ukraine (1919-1932)]. Problems of Ukrainian history: facts, judgments, searches, 2, 52-60. Kyiv [in Ukrainian].

Zvezda (Ekaterinoslav). (1923), 26 Sept. [in Russian].

Zinchenko, A.G. (1998). Bezprytulnist yak sotsialne yavyshche (Do istorii rozviazannia problemy). [Homelessness as a social phenomenon (To the history of problem solving)]. Social policy and social work, (1/2), 78-85 [in Ukrainian].

Ivanenko, V.V. (2016). Holodne lykholittia 1921-1923 rokiv na Katerynoslavshchyni: pohliad cherez desiatylittia [The famine of 1921-1923 in the Ekaterinoslav region: a look through the decades]. Dnieper: historical and local lore research. (Vol. 14), (pp. 45-54). Dnipro: Oles Honchar Dnipro National University [in Ukrainian].

Ivanenko, V.V., \& Ishchenko, I.V. (2006). Ukraina nepivska: analiz sotsialnykh anomalii pivdennoho rehionu. [Ukraine nepivska: analysis of social anomalies of the southern region]. Dnepropetrovsk [in Ukrainian].

Kulchytsky, S.V. (1999). Ukraina mizh dvoma viinamy (1921-1939 rr.) [Ukraine between the two wars (1921-1939)]. Kyiv [in Ukrainian].

Kulchytsky, S.V., \& Movchan, O.M. (1993). Nevidomi storinky holodu 1921-1923 rr. v Ukraini [Unknown pages of the famine of 1921-1923 in Ukraine]. Kyiv [in Ukrainian].

Kulchytsky, S. (2013). Chervonyi vyklyk. Istoriia komunizmu v Ukraini vid yoho narodzhennia do zahybeli. U 3 kn. [The Red Challenge. History of communism in Ukraine from its birth to its death. In 3 books]. (Vol. 2). Kyiv [in Ukrainian]. Lytvyn, V.M. (2003). Ukraina: mizhvoienna doba (1921-1938 rr.). [Ukraine: the interwar period (1921-1938). Kyiv [in Ukrainian].

Movchan, O.M. (1991). Holod 1921-1923 rr. na Ukraini [The famine of 1921-1923 in Ukraine]. Problems of Ukrainian history: facts, judgments, searches, (1), 24-35. Kyiv [in Ukrainian].

Ostasheva, N.V. (1998). Na perelome jepoh... (Menonitskoe soobshhestvo Ukrainy v 1914-1931 gg.) [At the turn of the epochs... (Mennonite community of Ukraine in 1914-1931)]. Moscow [in Russian].

Parashchevina, O.S. (2005). Rol systemy narodnoi osvity u podolanni dytiachoi bezprytulnosti v 20-kh - pershii polovyni 30-kh rr. XX st. v Ukraini. [The role of the public education system in overcoming child homelessness in the 20 's - first half of the 30's of XX century in Ukraine]. Candidate's thesis. Dnepropetrovsk [in Ukrainian].

Salko, G.S. (1931). Bezprytulnist ta borotba z neiu. [Homelessness and the fight against it. Kharkiv]. Kyiv [in Ukrainian].

Sotsialni indykatory zhyttia naselennia: Statystychnyi zbirnyk Derzhavnoho komitetu statystyky Ukrainy [Social indicators of population life: Statistical collection of the State Statistics Committee of Ukraine]. (2000). Kyiv [in Ukrainian].

Tsentralnyi derzhavnyi arkhiv vyshchykh orhaniv derzhavnoi vlady ta upravlinnia Ukrainy (TsDAVO) [The Central State Archives of Supreme Bodies of Power and Government of Ukraine (TsDAVO)] [in Ukrainian].

Czech, S.M. (1953). [Measures of the Communist Party and the Soviet Government to combat child homelessness in the period 1917-1923]. Candidate`s thesis. Kyiv [in Ukrainian].

Ivanenko Valentyn

Dr. Sc., Full Prof., https://orcid.org/0000-0002-4731-6702, ivanenko_dnu@i.ua 